\title{
PENGEMBANGAN PASAR TRADISIONAL SONGGOLANGIT PONOROGO: TINJAUAN PERSPEKTI EKONOMI ISLAM
}

\author{
Ahmad Lukman Nugraha, Mechio Lesmana, Royyan Ramdhani Djayusman \\ Universitas Darussalam Gontor Ponorogo \\ Email: ahmad.lukman.n90@gmail.com,mechiolesmana@gmail.com, \\ royyan@unida.gontor.ac.id
}

\begin{abstract}
This study aims to analyze traditional market development Songgolangit Ponorogo from an Islamic economic perspective. This study used a qualitative method. Qualitative methods are used to analyze the role of traditional market development from the perspective of Islamic Economics. Including data tecnic by copersition, dokumentation, and Focus Group Discossion. The results of this study indicate that the management of the Songgolangit market is good. Development of the Ponorogo Songgolangit traditional market through the stages of planning, organizing, field action, supervision and evaluation. Market development in Islamic perspectives includes price monitoring, fraud control, general supervision, quality control and halal goods, control of stockpiling, and control of prohibited transactions. Local governments play an important role in supervision and need to work together with the MUI in forming "rijalu-n-nisbah" in traditional markets.

Key Keywords: Market Development, Traditional Markets, Islamic Economics, Government Role.
\end{abstract}

Abstrak : Penelelitian ini bertujuan untuk menganalisa pengembangan pasar tradisional Songgolangit Ponorogo dalam prepektif ekonomi islam. Metode penelitian dalam paper ini adalah metode kualitatif. Metode kualitatif digunakan dalam menganalisa pengembangan pasar tradisional dalam perspektif ekonomi islam. Teknik pengumpulan data menggunakan wawancara, dokumentasi, dan Focus Discossion Group (FGD). Hasil penelitian ini menunjukkan bahwa pengelolaan pasar Songgolangit sudah baik. Pengembangan pasar tradisional Songgolangit Ponorogo melalui tahapan perencanaan, pengorganisasian, aksi lapangan, pengawasan dan evaluasi. Pengembangan pasar dalam prespektif islam menliputi pengawasan harga, pengendalian penipuan, pengawasan umum, pengendalian kualitas dan kehalalan barang, pengendalian penimbunan, dan pengendalian transaksi terlarang. Pemerintah daerah sangat berperan dalam pengawasan dan perlu bekerja sama dengan MUI dalam membentuk "rijalu-n-nisbah" dalam pasar tradisional.

Kata kunci : Pengembangan Pasar, Pasar Tradisional, Ekonomi Islam, Peran Pemerintah.

\section{A. PENDAHULUAN}

Data Ikatan Pedagang Pasar Indonesia (IKAPPI) Jumlah pasar tradisional pada tahun 2007 di Indonesia adalah 13.540 pasar, sedangkan pada tahun 2011 jumlah pasar tradisional adalah 9.950 pasar. Terjadi penurunan $26 \%$ dengan jumlah 3.590 pasar yang hilang dalam kurun waktu 5 tahun.

Data Kementrian perdagangan dan industri menunjukkan jumlah pasar 2007 adalah 13.750 pasar, sedangkan pada tahun 2011 jumlah pasar adalah 9.950 pasar. Terjadi penurunan $27 \%$ dalam kurun 5 tahun. Secara data, pasar tradisional mengalami $-8,1 \%$ penyusutan pertahun, sedangkan pasar modern melonjak jauh meningkat $31,4 \%$ petahun. ${ }^{1}$

Penurunan jumlah pasar tradisional ini diakibatkan oleh kondisi pasar itu sendiri. Kondisi pasar tradisional yang identik dengan kotor, becek, semrawut dan tidak teratur. Kondisi pasar tradisional yang lebih buruk dan tertinggal menyebabkan pasar tradisional sulit bersaing dengan pasar modern. Salah satu indikator menurunnya daya 
saing pasar tradisional dibuktikan dari tingkat keuntungan tingkat keuntungan yang mengalami penurunan. Hal ini juga menunjukkan bahwa keberadaan ritel modern membawa dampak meningkatnya persaingan dalam mendapatkan konsumen, sehingga pedagang di pasar tradisional berusaha menurunkan margin keuntungan melalui mekanisme tawar menawar.

Endi Sarwoko (2008) meneliti dampak keberadaaan pasar modern terhaadap kinerja perdagangan pasar tradisional di wilayah kabupaten Malang. Sarwoko menyimpulkan konsumen di pasar tradisional didominasi oleh konsumen toko/warung yaitu konsumen yang berbelanja di pasar tradisional untuk tujuan dijual kembali. Produk yang dijual di pasar tradisional umumnya didominasi bahan makanan (sembako) dan sisanya adalah kebutuhan rumah tangga. namun tingkat keuntungan mengalami penurunan, hal ini menunjukkan bahwa keberadaan ritel modern membawa dampak meningkatnya persaingan dalam mendapatkan konsumen. Keberadaan pasar modern berdampak terhadap penghasilan pedagang pasar tradisional. ${ }^{2}$

\footnotetext{
2 Endi Sarwoko. 2008. "Dampak Keberadaan Pasar Modern Terhadap Kinerja Pedagang Pasar Tradisional di Wilayah Kabupaten Malang", Jurnal Ekonomi Modernisasi, (Vol. 4, No. 2, Juni 2008)
}

Utami Dewi dan F. Winarni (2013) menyatakan peran pemerintah dalam pengelolaan pasar tradisional adalah pemerintah daerah sebagai perumus kebijakan yang ditetapkan dalam peraturan daerah (PERDA). PERDA ini akan menjadi standar oprasional pelaksanaan (SOP) dinas pengelolaan pasar dalam program pelayanan administrasi perkantoran, pemeliharaan sarana dan prasarana kebersihan, ketertiban dan keamanan pasar, optimalisasi pemanfaatan lahan, pengelolaan retribusi dan pengembangan pasar. $^{3}$

Dengan adanya kebijakan pemerintah dalam peraturan daerah dalam pengelolaan pasar tradisional, seharusnya dapat mendorong kemajuan dan daya saing pasar tradisional dengan pasar modern. Keunggulan pasar tradisional seyogyanya dapat bersaing dan menjadi daya tarik bagi masyarakat, seperti; harga terjangkau, masih berlaku system transaksi tawar-menawar, upah buruh murah serta biaya retribusi yang terjangkau.. Hal ini sangat cocok dengan keadaan masyarakat Indonesia, khususnya golongan ekonomi menengah ke bawah. Namun, pada kenyataannya harapan tersebut masih sangat sulit untuk

3 Utami Dewi dan F. Winarni. 2013. "Pengembangan Pasar Tradisional Menghadapi Gempuran Pasar Modern di Kota Yogyakarta”, dalam Jurnal Ilmu Administrasi Negara (Agustus, 2013). 
dicapai oleh pasar tradisional dengan kondisi dan daya saing seperti halnya saat ini yang tergolong masih kalah dibandingkan dengan pasar modern.

Pasar Songgolangit telah berdiri sejak tahun 1827. Berawal dari nama pasar legi, pasar songgolangit menjadi salah satu pasar induk di ilayah kota ponorogo. Kota ponorogo sendiri masih menganut sytem "pancawarna" atau pasar tradisional harian jawa, seperti; pon, wage, legi, kliwon dan pon. Karena permintaan masyarakat ponorogo yang sangat tinggi, akhirnya pasar Legi (Songgolangit) tidak hanya buka di hari pasaran akan tetapi buka setiap hari. Pasar songgolangit terletak di jalan Soekarno-Hatta Ponorogo. Pasar ini telah mengalami perombakan sebanyak dua kali, karena terjadi kebakaran 1995 dan 2017. Namun pemerintah ponorogo sangat cepat dan tanggap dalam proses rekontruksi pasar induk Songgolangit.

Nama Songgolangit sendiri diambil dari nama Dewi Songgolangit yang merupakan putri mahkota dari Kerajaan Kediri dalam salah satu versi cerita asalusul Reyog Ponorogo. Dewi Songgolangit mempunyai paras wajah yang cantik dan berbudi pekerti luhur menjadi daya tarik bagi raja-raja dan putra mahkota di wilayah Pulau Jawa. Karena cerita yang populer tersebut, nama Dewi Songgolangit sangat terkenal di kota Ponorogo dan sekitarnya. Sebagai bentuk penghargaan terhadap kebudayaan yang mengharumkan kota Ponorogo, nama Pasar Legi yang telah terbakar hebat beberapa tahun lahu, kini telah berdiri bangunan pasar baru dan diberi nama Pasar Songgolangit. Pasar tersebut menjadi salah satu pusat perdagangan tradisional masyarakat Ponorogo.

Pasar adalah tempat pertemuan antara permintaan dan penaaran barang. Pertemuan permintaan dan penaaran barang menghasilkan titik temu harga keseimbangan. Dalam konsep islam, penentuan harga diserahkan kepada permintaan dan penawaran barang tersebut didalam pasar. Ekonomi islam menakankan "tijarotan antarhodin minkum" yang berarti saling suka, saling terbuka dan saling menguntungkan. Dalam islam, distorsi pasar diharamkan, seperti; tadlis, taghrir, ikhtikar, maysir karena menguntungkan salah satu pihak dan merugikan pihak lainnya. Sehingga perlu adanya pengawasan (hisbah) dalam hal ini. ${ }^{4}$

Kajian yang dilakukan pada penelitian ini adalah kajian terhadap pengembangan pasar tradisional

${ }^{4}$ Royyan Ramdhani Djayusman, Nugraha, Ahmad Lukman, Umam, Khoirul., 2018, Strategi Pengembangan Pasar Tradisional Songgolangit dalam Prespektif Ekonomi Islam, Islamics Economics Journal. Vol IV. No. 2, hlm. 22-47 
Songgolangit dalam Tinjauan Prespektif

Ekonomi Islam. Tujuan penelitian ini untuk menganalisa perkembangan pasar tradisional Songgolangit. Selanjutnya, analisa potensi dan permasalahan pasar dilakukan dengan pendekatan dan perspektif Ekonomi Islam, khususnya konsep pengawasan pasar (hisbah).

\section{B. METODE PENELITIAN}

Penelitian ini menggunakan metode penelitian kualitatif dengan menggunakan endekatan studi kasus. Metode kualitatif digunakan untuk menganalisa pengembangan pasar tradisional Songgolangit dalam perspektif Ekonomi Islam. Dalam penelitian ini digunakan pendekatan kualitatif khususnya pendekatan fenomenologis studi kasus. Denzin dan Lincoln (2009) memaparkan bahwa pendekatan kualitatif fokus kepada proses dan makna yang tidak dikaji secara ketat atau belum diukur (jika memang diukur) dari sisi kuantitas, jumlah, intensitas atau frekuensinya. ${ }^{5}$ Para peneliti kualitatif menekankan sifat realita yang terbangun secara sosial, hubungan erat antara peneliti dengan subjek yang diteliti dan tekanan situasi yang membentuk penyelidikan. Bonoma (1985) dalam Hussey (1997) menjelaskan bahwa pendekatan ini harus dibangun

${ }^{5}$ Norman K Denzin., Yvonna S. Lincoln., 2009. Handbook of Qualitative Research. Cetakan Pertama. Yogyakarta: Pustaka Pelajar. pada kesadaran penuh atau sensifitas pada konteks di mana sebuah rangkaian prilaku terjadi. $^{6}$

Objek penelitian ini adalah masyarakat pasar yang terdiri dari; pedagang pasar, Unit Petugas Pasar (UPP) Songgolangit Dinas Perdakum, dan Dinas Perdagangan, Koperasi dan UMKM Kota Ponorogo. Metode pengumpulan data dengan menggunakan teknik wawancara, observasi, dokumentasi dan Focus Group Discussion (FGD). Metode wawancara digunakan untuk menggali informasi dari pemerintah, pengelola pasar, pedangan dan pembeli. Sedangkan metode observasi dan dokumenter digunakan untuk memetakan kondisi internal dan eksternal dari pasar Songgolangit. Sedangkan metode FGD dilakukan untuk mendapatkan informasi mendalam terkait peran pemerintah dan strategi pengembangan pasar tradisional.

\section{HASIL DAN PEMBAHASAN}

\section{Manajemen Pasar Tradisional Songgolangit}

Istilah manajemen mengacu pada kata "to manage" yang berarti mangatur, mengurus atau mengelola. Seperti yang terjadi pada banyak bidang studi lainnya yang menyangkut human, maka managemen

6 Jill, Roger Hussey., 1997. Business Research: A Practical Guide for Undergraduate and Postgraduate Students. New York: Palgrave 
tergolongyang sulit didefinisikan.

Menurut Robert L Kats, manajemen merupakan suatu profesi yang menuntut persyaratan tertentu. Seseorang manajemen harus memiliki 3 (tiga) keahlian atau kemampuan hakiki, yaitu kompetensi secara konseptual, social (hubungan manusiawi) dan teknikal.

Manajemen sebagai suatu proses adalah cara sistematis melakukan pekerjaan bagi seseorang manajer dengan tidak memperdulikan kecakapan tertentu yang saling berkaitan untuk mencapai tujuan yang merekaa inginkan. Sedangkan manajemen juga dapat diartikan sebagai ilmu, karena teori-teori yang terdapat didalamnya mampu menuntun manajer dengan memberikan kejelasan akan apa yang harus mereka lakukan pasa situasi tertentu dan mampu memprediksi akibat-akibat dari keputusan yang diambilnya. Sekian banyak definisi manajemen, namun ada satu yang kiranya dapat dijadikan pegangan dalam memahami ilmu manajemen, yaitu manajemen adalah suatu proses yang terdiri dari rangkaian kegiatan, seperti perencanaan, pengorganisasian, pengarahan dan pengendalian/pengawasan, yang dilakukan untuk menentukan dan mencapai tujuan secara efisien dan efektif.

Dalam hal ini, Indonesia merupakan negara yang kaya akan sumber daya alamnya, sehingga mudah bagi penduduk indonesia untuk menghasilkan suatu barang baik berupa pokok maupun sekunder, seperti halnya barang-barang tersebut dapat mudah dijumpai di pasaran. Pasar merupakan tempat yang mempertemukan antara permintaan dan penewaran untuk setiap jenis barang, jasa dan sumber daya. Sejak zaman dahulu pasar merupakan sarana bagi masyarakat indonesia untuk dapat bertransaksi jual-beli khususnya pasar tradisional. Menurut keputusan presiden Republik Indonesia No. 112 tahun 2007, pasar tradisional adalah pasar yang dibangun dan dikelolah oleh Pemerintah, Pemerintah Daerah, Swastra, Badan Usaha Milik Negara dan Badan Usaha Milik Daerah termasuk kerjasama dengan Swasta dengan tempat usaha berupa toko, kios, los dan tenda yang dimiliki/dikelolah oleh pedagang kecil, menengah, swadaya masyarakat atau koprasi dengan sekala kecil, modal kecil dan dengan proses jual beli barang dengan melalui tawar- 
menawar. Selanjutnya, pasar dikatakan sebagai organisasi, melalui teori pengembangan organisasi, sekumpulan orang yang melakukan transaksi jual beli disebut organisasi pasar.

Melalui keputusan Presiden diatas maka pasar tradisional dapat dikembangkan melalui peran pemerintah ataupun swasta. Pengembangan dalam teori manajemen organisasi didefinisikan sebagai pengembangan keorganisasian yang meliputi serangkaian tindakan manajemen puncak suatu organisasi, dengan partisipasi para anggota keorganisasian, guna melaksanakan proses perubahan dan pengembangan dalam organisasi yang bersangkutan, hingga dari kondisi yang sedang berlaku sekarang, melalui proses yang berlangsung dalam waktu, dapat dilaksanakan aneka macam perubahan, hingga pada akhirnya dicapai kondisi yang lebih memuaskan dan lebih sesuai dengan lingkungan.

Sebuah pasar merupakan mekanisme yang melalui para pembeli dan para penjual dan berinteraksi untuk menentukan harga serta melakukan pertukaran barang dan jasa. Dalam suatu definsi yang umum, pasar merupakan tempat dimana para pembeli dan penjual berinteraksi menetukan harga dan mengadakan pertukaran barang dan jasa. Pasar Songgolangit merupakan salah satu pasar tradisional yang ada di Indonesia tepatnya di Kabupaten Ponorogo, pasar ini terletak di tengah kota sehingga mempermudah masyarakat dalam bertransaksi. Padahal seperti kita ketahui bahwa pasar tradisional menjadi salah satu jantung perekonomian masyarakat. Kedudukan pasar tradisional masih tetap penting dan menyatu dalam kehidupan masyarakat. Banyak masyarakat yang masih membutuhkan pasar tradisional dalam mencari pendapatan dan juga kebutuhan dalam transaksi jual beli. Pada sisi lain, eksistensi pasar tradisional yang terkesan kumuh, dagangan yang kurang higenis, masih rendahnya kesadaran pedagang untuk mengembangkan usahanya, dan belum optimalnya waktu oprasional pasar merupakan beberapa faktor tersisihnya pasar tradisionla di indonesia masih semeraut dan kurang memuaskan, dan akibatnya pasar tradisional kehilangan daya saingnya.

Dalam menjalankan kegiatan oprasional, perlu adanya rujukan seperti Standard Oprasional Procedur (SOP) yang jelas. namun tidak 
demikian halnya dengan pasar tradisional Songgolangit, sehingga kegiatan yang dijalankan belum memiliki acuan/standar yang jelas. Hal ini berdampak pada mutu kegiatan yang terkesan semeraut (tidak rapi), dan membuat kondisi pasar tidak nyaman. Oleh karena itulah, manajemen pemerintah dalam pengelolaan pasar tradisional Songgolangit sangat dibutuhkan, dalam hal ini ada 5 (lima) hal yang dilakukan pemerintah dalam pengelolaan pasar Tradisional Songgolangit yaitu, Perencanaan, Pengorganisasian, pengarahan, pengawasan danevaluasi.

$$
\text { Pada tahun 2017, pasar }
$$

Tradisional Songgolangit mengalami kebakaran hebat yang kedua kalinya, hinggal menghabiskan kerugian miliyaran rupiah. Melihat banyaknya permasalahan yang dihadapi pemerintah terutama dalam alokasi pedagang paska kebakaran yang menghanguskan pertokoan di lantai 2 (dua) pasar Tradisional Songgolangit. Oleh sebab itulah, pemerintah kabupaten Ponorogo segeran merencanakan program kerja yang mempermudah dalam menyelesaikan permasalahan tersebut. Dalam hal ini pemerintah menugaskan Dinas
Perdagangan, Koprasi dan Usaha Mikro untuk merancang program kerja yang bersifat jangka pandek, jangka Menengah dan jangka Panjang. Karena itulah, peneliti melakukan wawancara dengan salah seorang dari Dinas Perdagangan, Koprasi dan Usaha Mikro khususunya Bagian yang menangani pasar Tradisional Songgolangit. Berdasarkan hasil wawancara, perencanaan jangka pendek yang dilakukan pemerintah adalah dengan cara merelokasi pasar Tradisional Songgolagit paska kebakaran yang bersifat sementara, rerokasi yang di rencanakan pemerintah merupakan usulan para pedagang, walaupun sebenarnya pemerintah sudah merencanakan sejak paska kebakaran. Adapun jangka menengahnya ialah persiapan pembangunan kembali pasar Songgolangit dengan jangka pembangunan kurang lebih 3 (tiga) tahun dan sekaligus pergantian namanya menjadi pasar Legi.

“Jangka Pendek yang direncakanam oleh pemerintah ialah relokasi pasar karena pasca kebakaran, yang bersifat sementara . hal ini atas permintaan pedagang sendiri, sebenarnya pemerintah daerah sudah menawarkan untuk relokasi ditempat lain, karena mereka ndak mau harga mati, NKRI disitu ya silahkan. sedangkan Jangka menengah ialah persiapan pembangunan kembali pasar songgolangit Dengan jangka waktu pembangunan selama 3 tahun 
sekaligus penggantian nama dari pasar Songgolangit menjadi pasar legi"

Adapun jangka panjangnya, diharapkan pasar Songgolangit yang telah berganti nama menjadi pasar Legi yang dapat menjadi pasar Tradisional dengan manajemen modern, seperti halnya Bumi Serpong Damai. Sehingga pasar Tradisional Songgolangit nantinya sudah memenuhi Standar Nasiona Indonesia dan sudah memenuhi Standar Oprasional Pasar Rakyat, sehingga adanya petugas kebersihan, keamanan dan tata letak para pedagang yang teratur. Hal ini sama halnya yang disampaikan oleh bapak Sugiharto selaku Staf Bidang Pasar bagian Kasi Penerima di Dinas Perdagangan, Koprasi dan Usaha Mikro, menurutnya:

"Dalam Jangka panjang: diharapkan pasar Songgolangit dapat menjadi pasar tradisional dengan manajemen modern, seperti Bumi Serpong Damai serta ada Standar Nasional Indonesia dan Standar Operasional pasar Rakyat. Diharapkan menjadi pasar rakyat/pasar tradisional yang modern. Maksudnya pengelolaan manajemennya yang modern. Misalkan penataan barangnya disatukan jenisnya untuk Memudahkan terutama bagi konsumen sebagai petunjuk. Dampaknya bagi masyarakat pelayannanya bias nyaman, aman, bersih dan indah, bagi pedagang sendiri diharapkan bias meningkatkan pendapatan mereka secara ekonomi, omsetnya bertambah karena adanya daya

7 Wawancara dengan Kepala Dinas Perdakum Ponorogo, 23 Agustus 2018. tarik pasar yang bersih, nyaman, bagus dan lain-lain."

$$
\text { Pengorganisasian merupakan }
$$

proses mengkoordinasikan sumbersumber daya yang meliputi manusia, peralatan, bahan, uang dan waktu. Proses ini merupakan aktivitas yang paling menentukan dalam keefektifan pencapaian tujuan organisasi. Pada tahapan ini, pemerintah Ponorogo belum bisa melakukannya pekerjaan pada setiap bagian sesuai dengan Standar Oprasional Pasar Rakyat. Sehingga kinerja Unit Pelaksana Teknis Hanya sebagai penarik retribusi, hal inilah yang menyebabkan kondisi pasar yang semeraut. Dalam hal penarikan retribusi pedagang di pasar Songgolangit oleh pemerintah dikenai biaya seribu sampai dua ribu permeter, sesuai dengan Peraturan Daerah Kabupaten Ponorogo Nomor 14 Tahun 2011 Tentang Retribusi Jasa Umum dan Peraturan Daerah Kabupaten Ponorogo Nomor 15 Tahun 2011 Tentang Retribusi Jasa Umum.

Pengawasan merupakan proses memberikan arahan, prosedur kerja bagi kayawan agar dapat melaksanakan pekerjaan dengan cara yang paling baik, serta menciptakan Iklmi kerja yang kondusif bagi

8 Wawancara dengan Kepala Dinas Perdakum Ponorogo, 23 Agustus 2018. 
terlaksananya aktivitas yang telah ditetapkan. Dalam hal ini pemerintah telah mengarahkan stafnya untuk merencanakan target yang akan di capai kedepannya, salah satunya adalah menjadikan pasar Tradisonal Songgolangit sebagai pasar Rakyat yang berbasis modern dengan memenuhi Standar Oprasional Pasar Rakyat. Dalam hal ini langkah awal yang dilakukan oleh pemerintah yaitu melaksanakan relokasi pedagang secara bertahap, hingga setelah lebawan relokasi sementara selesai dikerjakan. Sesuai dengan hasil wawancara;

"Ukurannya adalah selama dia bias berjualan karena keterbatasan (relokasi), relokasi dimulai tahun ini. Diusahakn setelah lebaran relokasi sementara semi permanen diharapkan bertahan kurang lebih 3 tahun karena pembangunnya kan multiyers. Setelah relokasi jadi baru mereka pindah dan ditempatkan disitu.supaya mereka tetap tidak putus, setelahnya baru pembangunan pasar setelah 3 tahun." 9

Pengawasan, merupakan proses pembenaran apabila aktivitas melenceng dari tujuan organisasi. Sehingga proses ini diharapkan mampu menjamin keberlangsungan organisasi mencapai tujuan dan keefektifan manajemen dapat rerukur. Dalam penerapannya, pemerintah ponorogo melakukan perkumpulan bersama Unit Pelaksana Teknis terkait

9 Wawancara dengan Kepala Dinas Perdakum Ponorogo, 23 Agustus 2018.
Program Kerja yang akan dilakukan , dalam perkumpulan ini pemerintah membahas permasalahan, Pendapatan Asli Daerah dan solusinya serta pencapainnya. Perkumpulan yang dilaksanakan Dinas Perdagangan, Koprasi dan Usaha Mikro ini dilaksanakan minimal satu (1) bulan sekali, dan dalam kegiatannya strategi pemerintah dalam memberihan arahan ataupun evaluasi dengan cara teguran secara lisa bagi yang melanggar maupun yang belum menjalankan program kerja.

\section{Peran Pemerintah Dalam Pengembangan Pasar Songgolangit}

Di Indonesia banyak terdapat pasar tradisional, bahkan bagi kalangan daerah pasar tradisional merupakan jantung perekonomian sehingga peran pasar tradisional sangatlah dibutuhkan. Pasar Tradisional merupakan pasar yang dikelolah dengan manajemen yang lebih tradisional dan simple dari pada pasar modern, umumnya pasar tradisional terdapat di pinggiran perkotaan, jalan atau lingkungan perumahan. Menurut peraturan Presiden Republik Indonesia No. 112 Tahun 2007 Tentang Pasar Tradisional adalah pasar yang dibangun dan dikelola oleh Pemerintah Daerah, Swasta, Badan Usaha Milik Negara 
dan Badan Usaha Milik Daerah termasuk kerjasama dengan swasta dengan tempat usaha berupa toko, kios, los, dan tenda yang dimiliki/dikelola oleh pedagang kecil, menengah, swadaya masyarakat atau koperasi dengan usaha skala kecil, modal kecil, dan dengan proses jual beli barang dagangan melalui tawar menawar. Lebih lanjut menurut Perpres tersebut, pasar tradisional boleh berlokasi pada setiap sistem jaringan jalan, termasuk sistem jaringan jalan lokal atau jalan lingkungan pada kawasan pelayanan bagian kota/kabupaten atau lokal atau lingkungan (perumahan) di dalam kota/kabupaten.

Tipe pasar tradisional sebenarnya sangatlah beragam jenisnya, dan dalam pertumbuhannya telah berlangsung lama. Masingmasing pasar memantapkan peran, fungsi serta bentuknya sendiri-sendiri. Bila umumnya mereka berfungsi sebagai pasar pengecer, di kota-kota beberapa pasar berkembang menjadi pasar pengumpul, sementara di kotakota besar menjadi grosir. Beberapa pasar ada yang mengkhususkan pada penjualan komoditi tertentu, seperti hewan/ ternak, buah dan sebagainya. Waktu kegiatan perdagangannya pasar tradisional ini dikenal adanya pasar harian dan mingguan sesuai dengan kebutuhan masyarakat setempat akan komoditas pasar yang tidak selalu harus dipenuhi setiap hari. Pasar Songgolangit merupakan salah satu pasar tradisional yang termasu pasar harian yang berada di kabupaten ponorogo. Pasar inipun tidak luput dari yang namanya kekurangan dan permasalahan.

Banyaknya permasalahan yang dihadapi pasar tradisional Songgolangit membuat pemeritah harus ikut campur untuk mengatasinya, saat ini permasalahan pasar tradisional Songgolangit disebabkan pula oleh kondisi yang dimiliki oleh pasar tradisional pada umumnya. Berdasarkan fasilitas dan utilitas, pasar tradisonal Songgolangit dinilai kurang memadai. Selain itu tidak tersedianya petugas kebersihan, petugas keamanan, jalan pasar yang sempit serta kotor, fasilitas MCK kurang bersih serta paska kebakaran yang melanda pasar Tradisional Songgolangit. Selain itu meningkatnya taraf hidup dan perubahan taraf hidup serta berubahnya gaya hidup masyarakat. Ketika taraf hidup masyarakat meningkat, di samping membutuhkan ketersediaan berbagai 
macam barang yang lengkap dari kebutuhan primer hingga kebutuhan tersier, fasilitas pendukung seperti kenyamanan, kebebasan, ataupun jaminan harga murah dan kualitas barang baik juga menjadi bahan pertimbangan masyarakat.

Sama halnya dengan pasar Tradisional lainnya, dalam pengembangan pasar tradisional Songgolangit memiliki beberapa kendala, dari sisi ketertiban salah satu kendalanya adalah kurangnya kesadaran pedagang dalam mematuhi peraturan ataupun tatatertib yang telah dibuat oleh Unit Pelaksana Teknis dan Dinas Perdagangan, Koprasi dan Usaha Mikro. Oleh karena itu berbelanja di pasar tradisional Songgolangit kurang nyaman, dikarenakan banyaknya pedagang yang berjualan melebihi batsan yang telah diatur oleh pemerintah. Seperti yang disampaikan bapak Anang Wisnu Susilo dari hasil wawancara:

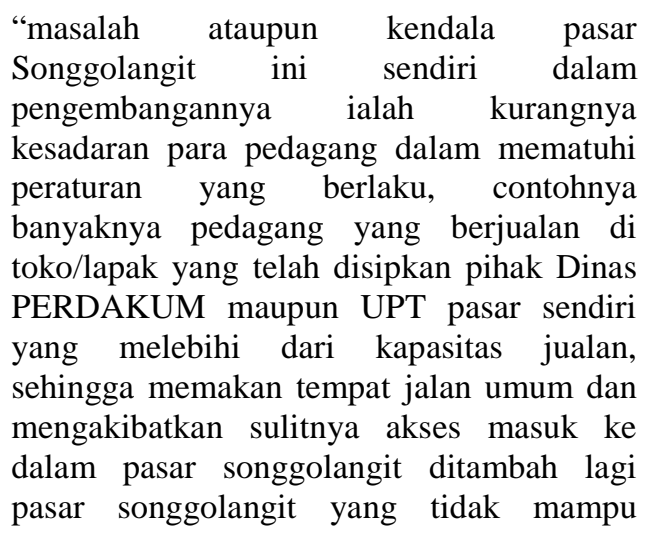

diluaskan dengan kapasitas lahan yang seadanya" 10

Sedangkan dari sisi kebersihan pasar Songgolangit terlihat kotor, inilah kendala lainnya yang dihadapi pemerintah setempat, menurut bapak Sugiharto selaku staf penerimaan di Dinas Perdagangan, Koprasi dan Usaha Mikro,

"kendala yang dihadapi pemerintah dalam
pengembangan pasar songglangit salah
satunya adalah dari sisi kebersihan,
dikarenakan kurangnya pekerja kebersihan
sehingga menyebabkan susahnya petugas
dalam menjaga kebersihan, hingga saat ini
pemerintah belum berani menambah petugas
kebersihan karena kurangnya Anggaran
Pendapatan, dan Belanja Daerah (APBD)
khususnya di Kabupaten Ponorogo" 11

Dari sisi keamanan, berjualan di pasar tradisional dipersepsikan kurang nyaman dan kuang aman. Hal inilah yang menyebabkan resahnya pemerintah setempat dalam menjaga keamanan. Dengan banyaknya para pedagang dengan jumlah kurang lebih 11036 (Seribu Seratus Tiga Puluh Enam), serta bermaca-macam dagangan yang diperjual belikan sehingga pemerintah kesulitan dalam menjaga keamanan, lebih lagi tidak adanya petugas keamanan di dalamnya. Hal inilah yang terjadi di kalangan para pedagang sebagaimana

${ }^{10}$ Wawancara dengan Anang Wisnu Susilo, Koordinator UPT Pasar Songgolangit. 23 Agustus 2018.

11 Wawancara dengan Sugiharto, Dinas Perdakum. 23 Agustus 2018. 
hasil wawancara peneliti dengan bapak Anang Wisnu Susilo;

"kendala lainnya yang dihadapi pedagang ialah dengan banyaknya dagangan para pedagang yang mengakibatkan pemerintah kesulitan dalam menjaga keamanan serta tidak adanya petugas keamanan di pasar Songgolangit yang di sebabkan karena terbatasnya Anggaran Pendapatan, dan Belanja Daerah (APBD)","12

Di lain sisi, kendala pemerintah yang paling besar adalah keterbatasan lahan bagi para pedagang, serat ketersedian fasilitas umum seperti mushola, toilet yang kotor dan lahan parkir yang kurang. Ditambah lagi dengan adanya pristiwa kebakaran yang menghanguskan seluruh dagangan serta toko yang ada di lantai 2 (dua) pada tahun 2017 silam. Yang menyebabkan para pedagang harus mencari tempat berjualan baru sampai bangunan pasar Songgolangit selesai di bangun kembali. Hingga saat ini pemerintah masih kewalahan dalam menangani kendala-kendala dan masih berusaha mencari solusi atas masalah tersebut.

Melihat kendala diatas, maka pemerintah kabupaten Ponorogo mengeluarkan kebijakan dalam mengembangkan pasar tradisonal Songgolangit. Kebijakan pengembangan pasar tradisional

${ }^{12}$ Wawancara dengan Anang Wisnu Susilo, Koordinator UPT Pasar Songgolangit. 23 Agustus 2018. sendiri disusun dalam meningkatkan perubahan di wilayah yang dituju sehingga terjadi pemerataan di wilayah pasar tradisional khususnya pasar Songgolangit. Dalam hal ini pemerintah telah melakukan beberapa pendekatan terkait proses pengembangan di pasar Songgolangit, adapun pendekatannya yang telah dilakukan pemerintah yaitu pendekatan secara fisik dan non-fisik.

Dalam hal ini, pendekatan secara fisik yang dimaksud oleh pemerintah adalah pendekatan secara nyata yang sifatnya membangun. Pengembangkan pasar Tradisional Songgolangit itu sendiri berupa perbaikan dan penambahan infrastruktur. Akan tetapi dalam pengembangan pasar Songgolangit sendiri pemerintah tidak dapat membangun ataupun menambah infrastruktur, dikarenakan tidak adanya lahan yang bisa untuk pembangunan pasar. Oleh karena itulah, dalam proses pengembangan pasar tradisional Songgolangit langka yang dapat dilakukan pemerintah Ponorogo khususnya Dinas Perdagangan, Koprasi dan Usaha Mikro (PERDAKUM) hanya sebatas Pemeliharaan dan Penambahan fasilitas yang kiranya tidak mengurangi ruang, seperti memelihara 
TPU (Tempat Pembungan Sampah), Memperbaiki pintu-pintu Kios yang rusak, memperbaiki lantai dan lainnya. Seperti yang dikatakan bapak Sugiharto selaku staff Dinas Perdagangan, Koprasi dan Usaha Mikro;

"Kalau pengembangan yang berbentuk penambahan fisik yang mengurangi lahan tidak ada, yang ada hanya pemeliharaan seperti tempat sampah, pintu-pintu, perbaikan lantai dan sebagainya." 13

Akan tetapi, pengembangan pasar tradisonal Songgolangit yang dilakukan pemerintah Ponorogo melalui pendekatan secara fisik belum terlalu sempurna sehingga pengaruh yang dirasakan oleh pedagang ataupun masyarakat tidak efisien.

Saat ini pengembangan pasar Songgolangit terhambat dikarenakan tragedi kebakaran yang menimpa pasar songgolangit akhir tahun 2017 silam, sehingga menghanguskan seluruh kios ataupun pertokoan di lantai 2 (dua) dan menyebabkan terhambatnya aktifitas jual-beli di pasar tersebut serta kurang nyamannya para penjual dan pembeli dan banyaknya para penjual yang menempati kios yang seharusnya secara teknik tidak boleh ditempati karena bangunan yang rapuh setelah kebakaran dan ditambah bangunan

13 Wawancara dengan Sugiharto, Dinas Perdakum. 23 Agustus 2018. yang terkena hujan dan panas. Sehingga yang dilakukan oleh pemerintah Ponorogo dalam hal ini Dinas Perdagangan, Koprasi dan Usaha Mikro adalah melakukan relokasi pedagang guna mempermudak aktifitas jual-beli yang rencananya para pedagang akan di relokasi ke tempat lain yang bisa menampung para penjual sementara, hingga pembangunan pasar Songgolangit selesai.

Selain pendekatan secara fisik, pemerintah Ponorogo juga menggunakan pendekatan secara nonfisik dalam proses pengembangan pasar tradisional Songgolangit. Pendekatan yang dilakukan Pemerintah Ponorogo khususunya Dinas Perdagangan, Koprasi dan Usaha Mikro berupa penerbitan peratura daerah (PERDA) tentang tata tertib dan tata kelola pasar Tradisional, Peraturan Bupati (PERBU) serta tatatertib pedagang yang tertera dalam bukti pemakaian tempat usaha (BPTU). Namun peraturan yang diterbitkan masih bersifat umum, masih terbatas pada peraturan retribusi dan belum menyangkut keamanan, kebersihan serta pelayanan masyarakat. Seperti yang disampaikan oleh bapak Sugiharto salah satu staff 
di Dinas Perdagangan, Koprasi dan Usaha Mikro;

"Peraturan yang membahas mengenai pasar tertera di Peraturan Daerah Nomor 14 tahun 2011 mengenai retribusi jasa umum meliputi retribusi pelayanan pasar, ada juga Peraturan Daerah nomor 15 tahun 2011 tentang retribusi jasa usaha meliputi sewa toko dan pemakaian tanah untuk kegiatan yang bersifat komersial." 14

Namun peraturan yang

diterbitkan oleh pemerintah Ponorogo

masih bersifat umum, hanya terbatas

pada pengaturan retribusi pasar,

Sedangkan di pasar Tradisional

Songgolangit hanya ada Unit

Pelaksana Teknsi (UPT) yang menjadi team pelaksana dari kebijakan Dinas Perdaganagn, Koprasi dan Usaha Mikro dan hanya sebatas penarikan retribusi dan tidak ada program kerja sebagai pengawasan pasar seperti layaknya pengawas pasar dalam Islam.

\section{Peran Pemerintah Dalam Pengembangan Pasar Tradisional Songgolangit dalam Prespektif Islam}

Sejarah dunia ekonomi menilai bahwa banyak kegagalan dalam mekanisme pasar, khususnya pasar Tradisional. Oleh karena itulah dibutuhkan campur tangan pemerintah dalam memperbaiki dan pengaturan kegiatan ekonomi dari kegagalan mekanisme tersebut. $^{15}$ Hal ini

14 Wawancara dengan Sugiharto, Dinas Perdakum. 23 Agustus 2018.

15 Saiful Hasan. 2016. Peran Pemerintah Dalam Perlindungan Pemberdayaan Pasar merupakan salah satu kebijakan publik yang di pegang oleh pemerintah agar kegiatan ekonomi yang dilakukan tidak menimbulkan penindasan dan ketidak setaraan di dalam masyarakat serta memastikan pertumbuhan ekonomi dapat diwujudkan dengan efisien. Dalam hal ini pasar Songgolangit merupakan salah satu contoh pasar Tradisional di Indonesia yang membutuhkan peran pemerintah dalam pengembangannya. Karena banyaknya permasalahan yang dihadapi oleh pasar tradisional sendiri dari internal ataupun eksternal. Maka daripada itu dibutuhkan peran dari pemerintah dalam mengawasi dan mengontrol pasar tradisional tersenu agar dapat berkembang.

Dalam islam lembaga yang mengontrol pasar dan adat moral disebut hisbah. menurut ibnu Taimiyah fungsi hisbah adalah untuk memerintahkan apa yang sering disebut dengan kebaikan dan mencegah apa yang secara umum diketahui sebagai keburukan. Dalam hal ini, peran hisbah yang berkaitan dengan peran pemerintah Ponorogo dalam pengembangan pasar Tradisional adalah:

Tradisional di Kota Makassar. Makassar: Universitas Hasanuddin. 


\section{Pengawasan Harga Barang}

dalam Pasar: Ekonomi islam mempunayi identitinya yang sendiri. Ia bukanlah semata-mata diasaskan untuk medapat keuntungan tanpa mengambil pertimbangan terhadap agama dan mudharat yang mungkin timbul bagi masyarakat. Sehubungan dengan ini, muhtasib berperan dalam menjaga kesetabilan harga dalam pasar agar tidak terjadi kecurangan dan ketimpangan, serta untuk kemaslahatan bagi masyarakat yang akan membelinya. Muhtasib memiliki perhatian yang besar dalam setiap perkembangan harga dan pengawasan. Bahkan muhtasib secara langsung ke pasar untuk melihat secara nyata dan mengawasi keadaan pasar.

Dalam hal ini, peranan pemerintah Ponorogo dalam mengawasi harga barang dan Pasar adalah dengan mengontrol harga tiap bulannya, biasanya pengontrolan ini di lakukan oleh dinas Perdagangan, Koperasi dan Usaha Mikro khususnya Bagian Perdagangan, apabila harga barang naik maka yang dilakukan oleh Dinas adalah dengan cara kerjasama antara daerah guna menstabilkan harga barang serta memberikan surat himbauan ke para pedagang agar tidak melebihi, Walaupun yang menentukan harga adalah pasar bukan pemerintah, akan tetapi pemerintah berperan dalam mengontrolnya, seperti hasil wawancara dengan ibu Krisnawati selaku Bagian Perdagangan di Dinas Perdagangan, Koperasi dan Usaha Mikro:

"Untuk Harga Eceran Tertinggi tidak semuanya kita atur yang diatur sama mentri perdagangan itu beras, gula, minya dan daging prosen dan beras. Kalau yang lainnya itu ketika harganya pas tinggi kita hanya bias mencarikan solusinya kerjasama antar daerah seperti itu. Selama ini juga kita belum pernah kerjasama seperti itu yang kita pantau ya yang ditetapkan oleh HETnya aja. Kalau kita temukan di pedagang kita himbau jangan sampai melebihi Harga EceranTertinggi."16

Memberantas penipuan dan penyelewengan pada barang dan harga: Setiap transaksi dalam islam harus dilandaskan pada prinsip kerelaan antara kedua bela pihak (sama-sama ridha). Mereka harus mempunyai informasi yang sama sehingga tidak ada pihak yang merasa dicurangi karena terdapat kondisi dimana salah satu pihak tidak mengetahui informasi yang diketahui pihal lain. Maka dari itu, hisbah berperan dalam memberantas penipuan dan penyelewengan pada barang dan harga. Penipuan merupakan perkara yang sering terjadi dalam kegiatan ekonomi dalam sebuah masyarakat khususnya pasar, Oleh

\footnotetext{
${ }^{16}$ Wawancara dengan Krisnawati, Pedagang Pasar Songgolangit. 23 Agustus 2018.
} 
sebab itu islam memandang tinggi perniagaan yang jujur dan benar. Penipuan dapat terjadi dalam 4 (empat) hal, yakni dalam kuantitas, kualitas, harga dan waktu penyerahan.

Penipuan dalam kuantitas adalah seperti halnya pedagang yang menguragi takaran (timbangan) barang yang di jual. Dalam kualitas seperti penjual yang menyembunyikan cacat barang yang di tawarkannya. Penipuan dalam harga adalah memanfaatkan ketidak tahuan pembeli akan harg pasar dengan menaikan harga produk diatas harga pasar. Sedangkan dalam fiqh penipuan harga di sebut ghaban. Bentuk penipuan yang terakhir, yakni penipuan dalam waktu penyerahan, seperti petani buah yang mnejual buah diluar musimnya padahal si petani mengetahui dia tidak dapat menyerahkan buah yang dijanjikan pada waktunya. Dalam keempat bentuk penipuan di atas, semunya melanggar prinsip rela-samarela. Keadaan yang dicapai bersifat sementara, yakni sementara pihak yang ditipu tidak mengetahui bahwa dirinya ditipu. Di kemudian hari, yaitu ketika pihak yang ditipu mengetahui bahwa dirinya ditipu, maka dia tidak merasa rela.
Muhtashib sebagai lembaga pengawas pasar yang menangani dan memberantas penipuan serta penyelewengan para penjual pada barang dan harga, hendaknya mencegah perbuatan tersebut. Para muhtasib juga diberi kuasa untuk memeriksa dan menguji alat timbangan dan ukuran yang digunakan bahkan mereka juga hendak untuk memeriksa dan mengawasi tokoh yang menjual alat tersebut. Mereka juga berhak menghukum para penjual yang melakukan penipuan sesuai dengan tingkat penipuan yang dilakukan. Dalam hal ini, peran pemerintah Ponorogo dalam pengembangan pasar tradisional Songgolangit dalam memberantas penipuan dan penyelewengan pada harga dan barang belum terlalu terlihat, karena tidak adanya papan informasi di pasar Songgolangit. seharusnya yang dilakukan oleh pemerintah Ponorogo khususnya Dinas perdagangan, Koperasi dan Usaha Mikro yang langsung diambil kendali oleh Unit Pelaksana Teknis yaitu menyediakan papan informasi harga di area pasar Songgolangit agar masyarakat yang ingin membeli barang di pasar tersebut tidak tertipu oleh penjual maupun pedagang. Sedangkan penipuan yang 
bersifat kuantitas dan kualitas, hingga saat ini belum ada tindakan pemerintah ataupun peraturan yang di keluarkan oleh pemerintah sehingga masyarakat sulit untuk memilah mana barang yang bagus ataupun tidak bagus.

\section{Pengawasan}

terhadap

keseluruhan pasar: Dalam hal ini muhtasib harus menjamin segala bentuk kebutuhan agar persaingan di pasar dapat berjalan dengan sehat dan islami. Salah satunya adalah kebutuhan fisik pasar, seperti pertokoan, kebersihan dan hal lainnya yang menyangkut kepentingan bersama. Dalam hal ini peran pemerintah ponorogo khususnya dinas perdagangan, koperasi dan usaha mikro adalah dengan menambah serta memelihara infrastruktur yang ada di pasar tradisional Songgolangit yang mana penambahan infrastruktur tidak menghabiskan ruang pasar, karena kondisi pasar sendiri yang tidak mampu untuk diperluas lagi. Adapun fasilitas yang ditambah berupa pembangunan gedung, lahan parkir, keamanan, toilet dan lainnya. Pemerintah Ponorogo juga menyediakan peraturan bagi para pedagang yang mampu untuk menertibkan pasar selama aktivitas berlangsung, serta pemerintah beruhasa dalam menjaga kenyamana para pembeli.

Pemastian barang halal: Pasar islam mempunyai identitinya yang tersendiri. Ia bukan semata-mata didasarkan untuk mendapatkan keuntungan tanpa mengambil pertimbangan terhadap agama yang mungkin timbul bagi masyarakat. Sehubungan dengan ini, islam menetapkan setiap barang yang dipasarkan hendaklah dipastikan halal dan bermanfaat bagi pengguna. Barang yang haram dan mendatangkan kejelekan hendaklah dicegah untuk di jual kepada masyarakat. dalam hal ini muhtasib berkuasa menghukum orangorang yang melakukan kemungkaran tersebut. Berbeda halnya dengan peranan pemerintah Ponorogo dalam mengembangkan pasar tradisional Songgolangit, dalam hal ini, pemerintah belum mengeluarkan peraturan daerah mengenai penjualan di pasar harus bersifat halal, khususnya Dinas Perdagangan, Koperasi dan Usaha MIkro yang berfungsi sebagai pengawas atas pasar tersebut.

\section{Memberantas penimbunan}

barang (ikhtikar): Penimbunan merupakan pembelian makanan 
semasa harga naik dan menyimpannya untuk di jual semasa harga tinggi. Jelasnya perbuatan penimbunan yang diharamkan merupakan suatu ke dzaliman terhadap kemanusiaan yang perlu di perangi dan di cegah. Hisbah memainkan peranan dalam mengawasi dari merebaknya kegiatan penimbunan dalam suatu Negara. Muhtasib juga boleh memaksa muhtakir menjual barangnya dengan harga pasaran kepada masyarakat yang memerlukan. Dalam hal ini, peran pemerintah Ponorogo dalam mengembangkan pasar tradisional Songgolangit dalam hal mencegah penimbunan belum ada, dari hasil wawancar oleh pak nanang, bahwasannya dalam mekanisme pasar tradisional Songgolangit belum pernah ditemukan adanya penimbunan barang, oleh karena itu, tidak adanya peran pemerintah untuk memberantas penimbunan.

Melarang akad dan transaksi yang diharamkan: Hisbah juga bertanggungjawab mengawasi berbagai akad dan macam-macam transaksi yang mengandung undur riba, sedangkan riba sendiri terdapat dalam berbagai akad seperti pembayaran angsuran, tukar menukar logam dan hutang. Dalam bidang perniagaan islam menetapkan setiap urusan niaga harus bebas dari hutang. Muhtasib selaku pihak yang bertanggungjawab terhadap perniagaan di pasar hendaklah memantau dan mencegah setiap unsur niaga yang melibatkan riba. Mereka diberi kuasa untuk mengukum para pelakunya apabila didapati bersalah karena ia merupakan erkara mungkar yang wajib di cegah. Dalam hal ini, belum ada peranan pemerintah Ponorogo dalam memberantas riba baik dari segi anjuran maupun aturan.

\section{Tabel 1 Bidang Pengawasan Pasar dalam Perpektif Islam dan Peran Pemerintah di Pasar Songgolangit}

\begin{tabular}{|c|c|}
\hline $\begin{array}{c}\text { Bidang } \\
\text { Pengawasan }\end{array}$ & Peran Pemerintah \\
\hline $\begin{array}{c}\text { Pengawasan } \\
\text { Harga }\end{array}$ & $\begin{array}{l}\text { Peran pemerintah berupa } \\
\text { pemantauan harga yang } \\
\text { dilakukan setiap bulan } \\
\text { yang dilakukan oleh Dinas } \\
\text { Perdakum. Apabila harga } \\
\text { tidak wajar dan melebihi } \\
\text { harga normal di daerah } \\
\text { sekitar Ponorogo, maka } \\
\text { petugas memberikan surat } \\
\text { himbauan kepada } \\
\text { pedagang untuk } \\
\text { menyesuaikan harga dan } \\
\text { tidak melebihi harga } \\
\text { pasaranan yang normal } \\
\text { pada saat itu. }\end{array}$ \\
\hline $\begin{array}{c}\text { Pengendalian } \\
\text { Penipuan }\end{array}$ & Belum ada. \\
\hline $\begin{array}{l}\text { Pengawasan } \\
\text { Umum }\end{array}$ & $\begin{array}{l}\text { Peran pemerintah berupa } \\
\text { pengadaan dan perawatan } \\
\text { fasilitas pasar. Selain itu, } \\
\text { untuk menjaga ketertiban } \\
\text { pasar, pemerintah } \\
\text { menerbitkan peraturan } \\
\text { bagi pedagang sehingga } \\
\text { para pengunjung merasa } \\
\text { nyaman } \\
\text { berbelanja. }\end{array}$ \\
\hline Pengendalian Kualitas & Belum ada. \\
\hline
\end{tabular}


dan Kehalalan Barang

Pengendalian

Penimbunan

Belum ada. (ikhtikar)

Pengendalian Jenis

Transaksi yang Dilarang

Sumber: Wawancara, 2018

\section{KESIMPULAN}

Pengembangan pasar tradisional Songgolangit Ponorogo sudah melalui manajemen Dinas perdagangan Koperasi, dan UMKM sudah memenuhi tahaan manajemen. Manajemen pengembangan pasar melalui tahapan perencanaan, pengorganisasian, aksi lapangan, pengawasan dan evaluasi.

Pengembangan pasar dalam prespektif islam 1) melalui pengawasan harga, 2) pengendalian penipuan, 3) pengawasan umum, 4) pengendalian kualitas dan kehalalan barang, 5) pengendalian penimbunan, dan 6) pengendalian transaksi terlarang. Peran Pemerintah Ponorogo sudah mengaplikasikan pengaasan harga dan pengawasan umum, namun belum melaksanakan lainnya, seperti; penipuan, kehalalan barang, penimbunan, dan transaksi yang dilarang. Pemerinrtah Daerah Ponorogo dapat bekerjasama dengan Majelis Ulama Indonesia (MUI) wilayah Ponorogo dan Prov. Jawa Timur dalam membentuk "rijalu-n-nisbah"
(Badan Pengawasan Pasar) dalam pasar tradisional.

\section{DAFTAR PUSTAKA}

Arianty, Nel. 2015. Analisis Perbedaan Pasar Modern dan Pasar Tradisional Ditinjau Dari Strategi Tata Letak (lay out) dan Kualitas Pelayanan Untuk Meningkatkan Posisi Tawar Pasar Tradisional. Medan: Universitas Muhammadiyah Sumatra Utara.

Arif, K. 2013. "Dampak Sosial Ekonomi Keberadaan Pasar Modern Pada Pasar Tradisional", Jurnal Ekonomi, (Ed. 15 Tahun 2013).

Denzin, Norman K., Yvonna S. Lincoln., 2009. Handbook of Qualitative Research. Cetakan Pertama. Yogyakarta: Pustaka Pelajar.

Dewi Utami dan F. Winarni. 2013. "Pengembangan Pasar Tradisional Menghadapi Gempuran Pasar Modern di Kota Yogyakarta", dalam Jurnal Ilmu Administrasi Negara (Agustus, 2013).

Djayusman, Royyan Ramdhani, Nugraha, Ahmad Lukman, Umam, Khoirul., 2018, Strategi Pengembangan Pasar Tradisional Songgolangit dalam Prespektif Ekonomi Islam, Islamics Economics Journal. Vol IV. No. 2: 22-47.

2018, Peran Pemerintah dalam Pengembangan Pasar Tradisional Dalam Perpektif Ekonomi Islam, Laporan Penelitian Dosen Pemula Hibah Dikti. Jakarta.

Hasan, Saiful. 2016. Peran Pemerintah Dalam Perlindungan Pemberdayaan Pasar Tradisional di Kota Makassar. Makassar: Universitas Hasanuddin.

Hussey, Jill, Roger Hussey., 1997. Business Research: A Practical Guide for 
Undergraduate and Postgraduate Students. New York: Palgrave.

Lesmana, Mechio, 2017, Peran Pemerintah Dalam Pengembangan Pasar Tradisional (Studi Kasus Pasar Songgolangit, Ponorogo), Skripsi, Program Studi Ekonomi Islam, Fakultas Ekonomi dan Manajemen, Universitas Darussalam Gontor, Ponorogo.

Malano, H., 2011. Selamatkan pasar tradisional: potret ekonomi rakyat kecil. Gramedia Pustaka Utama.

Nasution, Yeni Samri Juliati., 2018, Mekanisme Pasar Dalam Perspektif Islam. Jurnal At-Tawashuth. Vol III. No.1, 2018: 1-22.

Nugraha, Ahmad Lukman. dkk, 2018, Strategi Pengembangan Pasar Tradisional. Prosseding Forum Menejemen Indonesia ke 10 Palembang; 163

Pradipta, A.A. Gede Prathiwi. 2015. Pengaruh Revitalisasi Pasa Tradisional dan Sumber Daya Perdagang Terhadap Kinerja Pedagang Pasar di kota Denpasar. Bali: Universitas UDAYANA.

Sarwoko, Endi. 2008. "Dampak Keberadaan Pasar Modern Terhadap Kinerja Pedagang Pasar Tradisional di Wilayah Kabupaten Malang", Jurnal Ekonomi Modernisasi, (Vol. 4, No. 2, Juni 2008). 